\title{
Analysis of the Ability of Principal in Developing Policies to Maintain Education Quality in the Pandemic Covid-19 Era
}

\author{
Nurfatimah ${ }^{1}$, \\ ${ }^{1}$ Student of the Master of Islamic Education Management Program, Postgraduate, UIN Sulthan Thaha Saifuddin-Jambi \\ Email: pemaindibaliklayar@gmail.com \\ Sukarno $^{2}$ \\ ${ }^{2}$ Science Education (Physics) Department, Faculty of Tarbiyah and Teacher Training, UIN Sulthan Thaha Saifuddin-Jambi \\ Email: sukarno@uinjambi.ac.id
}

Kemas Imron Rosyadi ${ }^{3}$

${ }^{3}$ Educational Management Department, Postgraduate, UIN Sulthan Thaha Saifuddin-Jambi Email: kemasimronrosadi@uinjambi.ac.id

DOI: $10.31364 / S C I R J / v 8.112 .2020 . P 1220823$

http://dx.doi.org/10.31364/SCIRJ/v8.i12.2020.P1220823

\begin{abstract}
This study aims to analyze the ability of school principals to develop policies in maintaining the quality of education in the era of the COVID-19 pandemic. This research at SD Negeri 161/X Simbur Naik, Muara Sabak Timur Subdistrict, Tanjung Jabung Timur Regency, Jambi Province uses a qualitative approach with the research subjects being the principal, vice-principal, teachers, and educational staff as well as the documentation of related activities. The data sources in this study were school principals (primary data sources) and deputy principals, teachers, and education staff (secondary data sources) as well as documentation of related activities (tertiary data sources). To ensure the quality or validity of the data in this study, two important activities were carried out, namely reduction and triangulation. The results of the study show that in general, the ability of school principals to develop educational policies to maintain the quality of education in the era of the COVID-19 pandemic is good. This can be seen from five indicators, namely: 1) the ability to understand government policies related to the implementation of learning in the COVID19 pandemic era, 2) the ability to implement and adapt educational policies at the school level, 3) the ability to identify and analyze problems that occur, 4) the ability to look for alternatives to online learning problems, and 5) the ability to maintain teacher performance during the COVID-19 pandemic. The five indicators as a whole have been carried out by the principal optimally.
\end{abstract}

Keywords: Principal, Maintain Education Quality, Pandemic Covid-19 Era

\section{INTRODUCTION}

The 2019 Coronavirus disease pandemic (COVID-19) is an ongoing problem in more than 200 countries around the world. According to Siahaan (2020), Indonesia is one of the countries infected with Covid-19 pandemic. Indonesia was badly affected by COVID-19 with a case fatality rate (CFR) of $8.9 \%$ at the end of March 2020 (Setiati \& Azwar, 2020). In early 2020, COVID-19 became a world health problem. This case began with information from the World Health Organization (WHO) on December 31, 2019, which stated that there were cluster cases of pneumonia with unclear etiology in Wuhan City, Hubei Province, China. This case continues to develop until there are reports of deaths and imports outside China (Kemenkes RI, 2020).

The COVID-19 pandemic that has spread in the end carries a very bad risk for the world economy including Indonesia, especially in terms of tourism, trade, and investment (Nasution, Erlina, \& Muda, 2020). Covid-19 is an infectious disease that has the potential to cause a public health emergency. Therefore, preventive measures against these types of infectious diseases must be carried out as soon as possible. Indonesia as a rule of law, then the prevention of these types of infectious diseases must be established in a rule or regulation (Telaumbanua, 2020). The same thing was expressed by Yunus \& Rezki (2020) that Indonesia has experienced a condition where public concern about Covid-19 is quite large so that a government policy is needed to carry out a lockdown, as an effort to break the chain of spreading the Covid-19 coronavirus.

One of the government policies in the education sector as an effort to prevent COVID-19 is the temporary closure of the learning process in schools as a result of the program so that the stay at home or work from home (WFH) program is implemented as an effort to suppress the expansion of covid-19 (Khasanah, et .al., 2020). In this regard, the Ministry of Education and Culture takes a firm stance through several circular letters relating to education policy in the emergency period of the spread of Covid-19 (Arifa, 2020).

Implementation of learning must be carried out online using the internet network. The temporary closure of educational institutions to contain the spread of the Covid-19 pandemic (Siahaan, 2020) so that has an impact on the learning process of informal educational institutions. This is also in line with Windhiyana's (2020) statement that during COVID-19 the 
learning model of informal educational institutions was drastic; All learning activities are carried out online, starting from elementary school to university level. This situation of course has an impact on the psychology of students and decreases the quality of student skills (Syah, 2020). This was also conveyed by Nurkholis (2020) that online learning has a psychological impact on students.

This burden is the responsibility of all elements of education, especially the state in facilitating and assisting the continuity of schools for all educational stakeholders to carry out distance learning (Aji, 2020). The mentoring and facilitation process includes planning, implementing online learning. The implementation of online learning can take advantage of the Zoom, Google Classroom, Schoology, and Edmodo applications (Windhiyana, 2020). Arizona, at al. (2020) also states that there are at least 12 other free applications as media and online learning resources that can be used in the midst of the Covid-19 pandemic, namely Rumah Belajar, Meja Kita, Icando, Indonesia X, Google for Education, Smart Class, Microsoft Office 365, Quipper School, Ruangguru, Sekolahmu, Zenius, and Cisco Webex. In several schools, it shows that the impact of covid on the implementation of online learning in elementary schools can be implemented quite well (Dewi, 2020). Likewise, research conducted by Darmalaksana, et al. (2020) concluded that online learning as a challenge for digital leaders in $21 \mathrm{st}$ century higher education has proven to be effective in the WFH era due to the pandemic.

Apart from the positive impact of COVID-19 on the learning process informal educational institutions, the implementation of online learning also still has a negative impact. Is as stated by Arifa (2020) that there are still various obstacles in the implementation of online learning, both in terms of human resources, implementation arrangements, curriculum, and learning facilities. Windhiyana (2020) states that the obstacle in implementing online learning is the problem of internet connection that is not supportive. Besides, (Arizona et al., 2020) also mentioned that there were several obstacles in the application of online learning, including limited internet quota and the unfamiliarity of educators and students in applying it. Therefore, this learning technique is important to evaluate according to local conditions given the distribution of facilities and the ability of parents to provide different online learning facilities to students in Indonesia (Herliandry, Nurhasanah, Suban, \& Kuswanto, 2020).

Evaluation of the implementation of online learning is carried out to ensure that the quality of education is guaranteed even though the implementation of online learning. Is as stated by Fadhli (2017) that quality education is the hopes and demands of all education stakeholders. Also, Aziz (2015) states that efforts to improve to achieve quality education are not only fulfilling the input and output aspects but more importantly the process aspect. Given that during the COVID19 pandemic, the educational process was not running as usual (must be online), it is necessary to reflect and evaluate and take concrete steps so that the process can still be used as a reference in quality assurance of education.

Responding to various obstacles or problems in the implementation of online learning as described above, (Arizona et al., 2020) suggested that there should be more massive special efforts to overcome these problems starting from each individual, family support, educational institutions, service providers, and government. These special efforts at the school level are the responsibility of the principal as leader and manager. This is because the principal's leadership will affect the quality of education in schools. This fact is in line with the results of research by Ginting \& Haryati (2012) and (Manora, 2019) The principal as a school leader has high and full responsibility, directly in building commitment and working with all components in the school to develop the quality of education. Besides, Ekosiswoyo (2016) also said that effective principal leadership is the key to achieving the quality of education. Sampurno \& Wibowo (2017) stated that the principal's leadership and work environment on teacher work motivation.

Fitrah (2017) states that the role of the principal in improving the quality of education is monitoring, continuous evaluation of the success of the determined program, planning and drafting an agreed word plan with an increase in the need for quality education oriented to school missions, intensive communication with teachers, students, parents, and the community. The implementation of the role of the school principal as mentioned above has not yet come out of the education policies that have been established by the government, both central and local governments. This means that the principal must have the ability to analyze, adapt, and develop government education policies into implementing school principal policies. This is in line with the concept of implementing school-based management as an effort to improve the quality of education (Ismail, 2018).

Regarding the COVID-19 pandemic, the role of school principals in analyzing, adapting, and developing government education policies into implementing school principal policies is very important. This is intended in addition to implementing government policies (prevention of Covid-19), also to minimize various technical problems in implementing online learning. As mentioned by Handayani (2020), the shortcomings of online learning are network instability, teacher voices and teaching materials are not synchronous, they cannot take classes when wifi or the network is not connected, concentration is reduced. Sawitri, Astiti, \& Fitriani (2019) also said that one of the challenges and obstacles in the application of ICT-based learning is the inequality of infrastructure that supports the application of ICT in education. Therefore, the ability of the principal in analyzing, adapting, and developing government education policies becomes the principal's implementable policy, so these problems can be overcome.

Based on the description above, which is related to the COVID-19 pandemic situation that has not subsided and learning must be carried out online (for most schools in Indonesia - including in Jambi province, Muara Sabak district). On the other hand, the quality of education must be maintained and even improved. This situation raises the question of how the principal can maintain the quality of education in an unusual situation (because of COVID-19)? Therefore, this study aims to determine the ability of school principals to develop policies in maintaining the quality of education in the era of the Covid-19 pandemic.

\section{II.METHOD}

This research at SD Negeri 161/X Simbur Naik, Muara Sabak Timur Subdistrict, Tanjung Jabung Timur Regency, Jambi Province uses a qualitative approach with the research 
subjects being the principal, vice-principal, teachers, and educational staff as well as the documentation of related activities. The data sources in this study were school principals (primary data sources) and deputy principals, teachers, and education staff (secondary data sources) as well as related activity documentation (tertiary data sources). Data is collected through structured and unstructured interviews, so data collection is interactive (Rijali, 2019). The ability of school principals to develop policies to maintain the quality of education in the era of the COVID-19 pandemic is measured through 1) the ability to understand government policies related to the implementation of learning in the COVID-19 pandemic era, 2) the ability to implement and adapt educational policies at the level schools, 3) ability to identify and analyze problems that arise, 4) ability to look for alternatives to online learning problems and 5) ability to maintain teacher performance during the COVID-19 pandemic. To ensure the quality or validity of the data in the study, two important activities were carried out, namely reduction and triangulation. Data reduction is intended to select and sort data that is relevant to research and data that is not relevant to research. Data triangulation activities were carried out as suggested by H. Mudjia (2010). In this research is source triangulation, namely by comparing primary data sources and secondary data sources. If the two data match, then the data is considered valid, whereas if there is no match then a comparison is made with tertiary data (documentation). If there is a match between primary data and tertiary data then it is considered valid and if there is no match then it is invalid so the data is not used. After all, data is reduced, and triangulated, descriptive analysis is then carried out (Muhson, 2006) to make it easier to understand.

\section{RESULTS AND DISCUSSION}

Based on interviews with research sources, both primary, secondary, and tertiary, the following data were generated:

1) Ability to understand government policies related to the implementation of learning in the era of the COVID-19 pandemic.

As already stated, during the COVID-19 pandemic, the government has taken a policy to implement online learning. This is contained in Circular Number 2 of 2020 concerning the Prevention and Handling of Covid-19 in the Ministry of Education and Culture and Circular Number 3 of 2020 concerning Prevention of Covid-19 in the Education Unit. Also, there is a Circular (SE) of the Ministry of Education and Culture (Mendikbud) number 4 of 2020. Structurally, SE of the Minister of Education and Culture No. 4 of 2020 consists of two pages containing six important points. These points are respectively related to the National Examination, the learning process from home, School Exams, class promotion, New Student Admission, and School Operational Assistance (BOS) funds. Besides, government policies related to online learning are also based on a joint decree (SKB) of the Four Ministers issued on August 7, 2020, to adjust learning policies in the pandemic era. In the SKB, schools are given the flexibility to choose a curriculum that suits the learning needs of students during a pandemic, as stipulated in the Decree of the Minister of Education and Culture regarding curricula during an emergency. The regional government policies related to the field of education and learning during the COVID-19 pandemic are contained in the circular letter of the Regent of
Tanjung Jabung Timur Number 1188 / SE / BUP.ORG / 2020 dated June 5, 2020, concerning the Prevention and Control of Covid-19 in Carrying Out Official Duties for State Civil Apparatus in the Tanjung Jabung Timur Regency Government (Tanjabtim), During the New Life Order (New Normal) and Academic Activities on the Tanjabtim Regency Education Calendar for the 2019/2020 Academic Year.

The principal's knowledge and understanding of education policy as described above are generally relatively good. This is proven by the results of the interview that the head already knows and understands the policy well. This fact was also reinforced by a secondary source (deputy principal) that they had a meeting with the principal to discuss and make decisions regarding online learning during the COVID-19 pandemic based on the government policy above. Besides, based on tertiary data (documentation) it was also found that the circular was stored in the school principal's desk. Based on this evidence, it can be said that the level of understanding of school principals of government policies to online learning during the COVID-19 period is quite good.

Having the principal's understanding of the command policy is one of the best steps in maintaining the quality of education in this era of the COVID-19 pandemic. A good understanding of government education policies will foster confidence in the principal as a leader. This situation will encourage the emergence of effective leadership in educational institutions. Furthermore, this effective leadership plays a role in creating and maintaining the quality of education. This is in line with the opinion of Ekosiswoyo (2016) that effective leadership is the key to improving the quality of education. This is also reinforced by Said's (2018) opinion that effective principal leadership can develop and preserve a quality culture in schools. Thus, from this point of view, it is believed that the quality of education at SD Negeri 161/X Simbur Naik, Muara Sabak Timur District, Tanjung Jabung Timur Regency can be maintained during the COVID-19 pandemic.

\section{2) Ability to implement and adapt educational policies at the school level}

One indicator of the principal's ability to develop educational policies to maintain the quality of education during the COVID-19 pandemic is the principal's ability to implement the policy. As stated above, the implementation of learning during the COVID-19 pandemic must follow the policies set by the government. Therefore, the authority of the principal as the leader of the educational institution administering the educational process is to implement this policy while still considering the quality of education in his school. Thus, the principal's ability to implement and adapt policies can be used as an indicator of the principal's success in leading his school.

SD Negeri 161/X Simbur Naik, Muara Sabak Timur District, Tanjung Jabung Timur Regency, is one of the primary schools located in a rural area. The facilities and infrastructure to support the implementation of online education are not yet optimal. Apart from the limited internet network provider, the internet network signal is also unstable. Even the elementary school does not yet have online learning support facilities that can be provided independently by the school. Thus, the implementation of online learning during the COVID-19 pandemic as well as government policies has not been implemented optimally at this school. 
Seeing the limited means of supporting the implementation of online learning in his school and on the other hand there is an obligation to implement an online learning policy, the principal implements the policy by making several adjustments. Adjustments made by school principals to implement educational policies in the era of the COVID-19 pandemic include: 1) encouraging and motivating teachers to continue to carry out online learning as well as government policies in efforts to prevent the spread of COVID-19, 2) provide guidance and assistance. for teachers who have difficulty using online learning tools, including finding or developing online teaching materials, 3) giving teachers the freedom to use online learning models and applications, according to the teacher's abilities, 4) supervising and evaluating online learning carried out by the teacher to ensure the implementation of online learning is by the applicable curriculum.

Various policies undertaken by school principals to implement government policies to carry out online learning are also supported by secondary data and tertiary data. This, for example, can be seen from the evidence of coordination meetings conducted by school principals, deputy principals, and teachers in the context of implementing online learning. Besides, other evidence was also found (several learning applications and digital teaching materials) that were used by teachers in implementing online learning. Based on this evidence, it can be said that the ability of the principal in implementing government policies to implement online learning is good.

\section{3) Ability to identify and analyze problems that arise}

With the very limited facilities and infrastructure to support the implementation of online learning, the principal's ability to identify and analyze problems that arise is very much needed. Therefore, this ability is used as an important indicator in this study. The ability to identify and analyze problems is one form of information literacy skills. According to the Library (2016) information literacy is the ability to know when there is a need for information, to be able to identify, find, evaluate, and effectively use that information for the issue or problem at hand.

Regarding the implementation of online learning at SD Negeri 161/X Simbur Naik, Muara Sabak Timur District, the ability to identify and analyze problems that arise is a must. This is because the school is located in an area with limited facilities. Apart from the facilities, human resources (teachers) in implementing online learning are also still relatively low, because teachers (even in Indonesia) in general have never done online learning massively before. Another problem that arises related to online learning at these schools is that students are still very limited in their ability to take part in the online learning process. Apart from that, from a parent's point of view, they still have limitations, especially in providing internet quota as the main facility in online learning.

Knowledge of various problems that arise regarding the implementation of online learning at SD Negeri 161/X Simbur Naik, Muara Sabak Timur District indicates that the principal has good leadership skills, namely in terms of thinking. The ability to identify problems and analyze them is a form of directed thinking ability. Is as stated by Maulidya (2018) that directed thinking processes are thought processes that have been predetermined and directed at something, usually directed at solving a problem. Therefore, online learning implementation problems that have been identified and analyzed by the principal are part of the problem-solving process itself. This was also conveyed by Sholihah \& Afriansyah (2018) that problem identification is the initial stage in solving problems.

\section{4) Ability to find alternatives to online learning problems}

According to Ulya (2016), thinking is a life skill that involves the process of analyzing, interpreting, reasoning, predicting, evaluating, and reflecting. Therefore it can be said that the ability to look for alternatives to online learning problems is a thought process. The ability to think to find solutions to every problem is a necessity for every human being, including a school principal. The ability to think is one form of the learning process, namely the ability to think critically. This is in line with the opinion (Cahyono, 2016) that critical thinking is an important condition for everyone to solve problems. Thus the ability to find alternative solutions to problems in the context of online learning is a form of critical thinking skills.

As stated above, the implementation of online learning at SD Negeri 161/X Simbur Naik, Muara Sabak Timur District was followed by several problems that arose. Therefore it is necessary to know how the ability of the principal in finding alternative solutions to the problem. This is intended to determine the ability of school principals to develop educational policies to maintain the quality of education in this era of the COVID-19 pandemic. Several alternative solutions to problems that have been carried out by the principal related to the above problems, among others, are as follows: 1) with limited supporting facilities for the implementation of online learning, the principal makes a policy that allows the implementation of offline learning by observing very strict health protocols applies to students who do not have supporting facilities (android/smartphone). In this way, it is hoped that students will still have the right to learn properly and the curriculum is still implemented. 2) in terms of limited resources (the ability of teachers to use technology to teach online), the principal provides active assistance by inviting experts to assist teachers in planning, implementing, and assessing the learning process. 3) related to the limited ability of students to use technology for learning, the principal encourages teachers to actively communicate with parents to assist students when studying at home and use simple applications that are most likely to be accessed by students. In addition to alternative solutions to these problems, the principal is also actively communicating with the education office and school supervisors to ensure that online learning during the COVID-19 pandemic can run well.

By paying attention to the description above, it can be understood that the principal's ability to find solutions to any problems that arise is good. This also means that the principal's ability to develop educational policies at the school level can be said to be good. Various alternative solutions to these problems, theoretically, can guarantee the quality of education at SD Negeri 161 / X Simbur Naik, Muara Sabak Timur District. However, empirically, this policy still needs to be tested.

5) Ability to maintain teacher performance during the COVID-19 pandemic.

One important element in maintaining the quality of education is teacher performance. Theoretically, teacher performance can be understood as results, progress, and 
teacher work performance in carrying out learning, both in planning, implementing the learning process and evaluating learning outcomes, conducting guidance and training for students, and their commitment to carrying out tasks (Lailatussaadah, 2015). It is therefore clear that teacher performance greatly affects the quality of education. This is as stated by E. Mulyasa (2013) that quality Human Resources (HR) can only be engineered through education designed by professional and qualified teachers. Thus, teacher performance is the key to maintaining the quality of education.

In the era of the COVID-19 pandemic, learning is carried out online, and teachers are allowed to carry out learning from home (as a result of the COVID-19 prevention policy). In this situation the intensity of face-to-face meetings between the teacher and the principal of the cooperative school decreases. This situation also has an impact on the efforts of the principal in maintaining teacher performance in carrying out their duties. Therefore, the principal as a leader in the educational institution takes several initiatives (policies) to maintain teacher performance. Some of these policy initiatives include: 1) the implementation of online learning is carried out in schools by implementing health protocols (physical distancing), 2) providing assistance facilities for teachers who need assistance for the implementation of online learning, 3) school principal work together with supervisors to conduct supervision periodically to ensure the implementation of online lessons.

Through these three policy initiatives, the implementation of online learning at SD Negeri 161/X Simbur Naik, Muara Sabak Timur District can run relatively smoothly, teacher performance is controlled and the curriculum can be implemented. Therefore, based on the three policy initiatives above, it can be said that the principal's ability to maintain teacher performance is relatively good. Through these three policy initiatives, it was also seen that the principal's leadership abilities were relatively good. This is explained by Afriansyah (2018) that the ideal type of leader is to have intellect, religion, and morals, be able to influence the environment being led and be able to treat destruction and damage (solutions to the problems at hand) and bring a just and prosperous society with upholding science, as well as moral based on religion (quality of education).

\section{CONCLUSIONS AND SUGGESTIONS}

Referring to the data and description above, at the end of this study, it can be concluded that in general, the ability of school principals to develop educational policies in maintaining the quality of education in the era of the COVID19 pandemic is good. This can be seen from five points of view (indicators), namely: 1) ability to understand government policies related to the implementation of learning in the COVID-19 pandemic era, 2) ability to implement and adapt educational policies at the school level, 3) ability to identify and analyzing the problems that arise, 4) the ability to look for alternatives to online learning problems, and 5) the ability to maintain teacher performance during the COVID-19 pandemic. Thus further research is needed to ensure that the managerial pattern of school principals in dealing with the COVID-19 pandemic can be further developed and can be an inspiration for other school principals.

\section{ACKNOWLEDGMENT}

This research has involved many parties, from planning, implementing to writing reports and publications. For this reason, the researcher would like to thank all research subjects, namely the principal, vice principal, staff who have helped provide information/data so that the research can be completed. The researcher also expressed his special gratitude to the Principal of SD Negeri 161/X Simbur Naik, Muara Sabak Timur District who had given permission and supported this research

\section{REFERENCES}

Afriansyah, A. (2018). Konsep Pemimpin Ideal Menurut AlGhazālī. NALAR: Jurnal Peradaban Dan Pemikiran Islam. https://doi.org/10.23971/njppi.v1i2.905

Aji, R. H. S. (2020). Dampak Covid-19 pada Pendidikan di Indonesia : Jurnal Sosial \& Budaya Syar-I.

Arifa, F. N. (2020). Tantangan Pelaksanaan Kebijakan Belajar Dari Rumah Dalam Masa Darurat Covid-19. Info Singkat; Kajian Singkat Terhadap Isu Aktual Dan Strategis.

Arizona, K., Abidin, Z., \& Rumansyah, R. (2020). Pembelajaran Online Berbasis Proyek Salah Satu Solusi Kegiatan Belajar Mengajar Di Tengah Pandemi Covid-19. Jurnal Ilmiah Profesi Pendidikan.

Aziz, A. (2015). Peningkatan Mutu Pendidikan. Jurnal Studi Islam Peningkatan Mutu.

Cahyono, B. (2016). Korelasi Pemecahan Masalah dan Indikator Berfikir Kritis. Phenomenon: Jurnal Pendidikan MIPA. https://doi.org/10.21580/phen.2015.5.1.87

Darmalaksana, W., Hambali, R. Y. A., Masrur, A., \& Muhlas. (2020). Analisis Pembelajaran Online Masa WFH Pandemic Covid-19 sebagai Tantangan Pemimpin Digital Abad 21. Karya Tulis Ilmiah (KTI) Masa Work From Home (WFH) Covid-19 UIN Sunan Gunung Djati Bandung Tahun 2020.

Dewi, W. A. F. (2020). Dampak COVID-19 terhadap Implementasi Pembelajaran Daring di Sekolah Dasar. EDUKATIF : Jurnal Ilmu Pendidikan. https://doi.org/10.31004/edukatif.v2i1.89

E. Mulyasa. (2013). uji kompetensi dan penilaian kinerja guru. In uji kompetensi dan penilaian kinerja guru.

Ekosiswoyo, R. (2016). Kepemimpinan Kepala Sekolah yang Efektif Kunci Pencapaian Kualitas Pendidikan. Jurnal Ilmu Pendidikan. https://doi.org/10.17977/jip.v14i2.24

Fadhli, M. (2017). Manajemen Peningkatan Mutu Pendidikan. TADBIR: Jurnal Studi Manajemen Pendidikan. https://doi.org/10.29240/jsmp.v1i2.295

Fitrah, M. (2017). Peran Kepala Sekolah Dalam Meningkatkan Mutu Pendidikan. Jurnal Penjaminan Mutu. https://doi.org/10.25078/jpm.v3i1.90

Ginting, R., \& Haryati, T. (2012). Kepemimpinan dan Konteks Peningkatan Mutu Pendidikan. Jurnal Ilmiah CIVIS.

H. Mudjia Rahardjo. (2010). Triangulasi dalam Penelitian Kualitatif. https://doi.org/10.1360/zd-2013-43-6-1064

Handayani, L. (2020). Keuntungan , Kendala dan Solusi Pembelajaran Online Selama Pandemi Covid-19: Studi Ekploratif di SMPN 3 Bae Kudus Lina Handayani. Journal Industrial Engineering \& Management Research.

Herliandry, L. D., Nurhasanah, N., Suban, M. E., \& Kuswanto, H. (2020). Pembelajaran Pada Masa Pandemi Covid-19. JTP - Jurnal Teknologi Pendidikan. https://doi.org/10.21009/jtp.v22i1.15286

Ismail, F. (2018). Manajemen Berbasis Sekolah: Solusi 
Peningkatan Kcalitas Pendidikan. Jurnal Pendidikan Islam Iqra'. https://doi.org/10.30984/jpii.v2i2.541

Kemenkes RI. (2020). Pedoman Pencegahan dan Pengendalian Coronavirus Disease (COVID-19). Germas.

Khasanah, D. R. A. U., Pramudibyanto, H., \& Widuroyekti, B. (2020). Pendidikan Dalam Masa Pandemi Covid-19. Jurnal Sinestesia.

Lailatussaadah, L. (2015). Upaya Peningkatan Kinerja Guru. Intelektualita.

Manora, H. (2019). Peranan Kepala Sekolah Dalam Meningkatkan Mutu Pendidikan. Edification Journal. https://doi.org/10.37092/ej.v1i1.88

Maulidya, A. (2018). Berpikir dan Problem Solving. Berpikir Dan Problem Solving.

Muhson, A. (2006). Teknik Analisis Kuantitatif. Makalah Teknik Analisis II.

Nasution, D. A. D., Erlina, E., \& Muda, I. (2020). Dampak Pandemi COVID-19 terhadap Perekonomian Indonesia. Jurnal Benefita. https://doi.org/10.22216/jbe.v5i2.5313

Nurkholis. (2020). Dampak Pandemi Novel-Corona Virus Disiase ( Covid-19) Terhadap Psikologi Dan Pendidikan Serta Kebijakan Pemerintah. Pgsd.

Perpustakaan Universitas Indonesia. (2016). Literasi Informasi. Perpustakaan Universitas Indonesia.

Rijali, A. (2019). Analisis Data Kualitatif. Alhadharah: Jurnal Ilmu https://doi.org/10.18592/alhadharah.v17i33.2374

Said, A. (2018). Kepemimpinan Kepala Sekolah Dalam Melestarikan Budaya Mutu Sekolah. Journal EVALUASI. https://doi.org/10.32478/evaluasi.v2i1.77

Sampurno, D., \& Wibowo, A. (2017). Kepemimpinan Kepala Sekolah, Lingkungan Kerja, Motivasi Kerja, Dan Kinerja Guru Di SMK Negeri 4 Pandeglang. Jurnal Pendidikan Ekonomi Dan Bisnis (JPEB). https://doi.org/10.21009/jpeb.003.2.5
Sawitri, E., Astiti, M. S., \& Fitriani, Y. (2019). Hambatan Dan Tantangan Pembelajaran Berbasis Teknologi Informasi Dan Komunikasi. Prosiding Seminar Nasional Pendidikan Program Pascasarjana Universitas PGRI Palembang.

Setiati, S., \& Azwar, M. K. (2020). COVID-19 and Indonesia. Acta Medica Indonesiana.

Sholihah, S. Z., \& Afriansyah, E. A. (2018). Analisis Kesulitan Siswa dalam Proses Pemecahan Masalah Geometri Berdasarkan Tahapan Berpikir Van Hiele. Mosharafa: Jurnal Pendidikan Matematika. https://doi.org/10.31980/mosharafa.v6i2.317

Siahaan, M. (2020). Dampak Pandemi Covid-19 Terhadap Dunia Pendidikan. Jurnal Kajian Ilmiah. https://doi.org/10.31599/jki.v1i1.265

Syah, R. H. (2020). Dampak Covid-19 pada Pendidikan di Indonesia: Sekolah, Keterampilan, dan Proses Pembelajaran. SALAM: Jurnal Sosial Dan Budaya Syar-I. https://doi.org/10.15408/sjsbs.v7i5.15314

Telaumbanua, D. (2020). Urgensi Pembentukan Aturan Terkait Pencegahan Covid-19 di Indonesia. QALAMUNA: Jurnal Pendidikan, Sosial, Dan Agama. https://doi.org/10.37680/qalamuna.v12i01.290

Ulya, H. (2016). Profil Kemampuan Pemecahan Masalah Siswa Bermotivasi Belajar Tinggi Berdasarkan Ideal Problem Solving. Jurnal Konseling Gusjigang. https://doi.org/10.24176/jkg.v2i1.561

Windhiyana, E. (2020). Dampak Covid-19 Terhadap Kegiatan Pembelajaran Online Di Perguruan Tinggi Kristen Di Indonesia. Perspektif Ilmu Pendidikan. https://doi.org/10.21009/pip.341.1

Yunus, N. R., \& Rezki, A. (2020). Kebijakan Pemberlakuan Lock Down Sebagai Antisipasi Penyebaran Corona Virus Covid-19. SALAM: Jurnal Sosial Dan Budaya Syar-I. https://doi.org/10.15408/sjsbs.v7i3.15083 